\title{
Social Determinant of Health of Adult Smoking Behavior: Differences between Urban and Rural Areas in Indonesia
}

\author{
Determinan Sosial Kesehatan Perilaku Merokok pada Orang Dewasa: \\ Perbedaan antara Wilayah Pedesaan dan Perkotaan di Indonesia
}

Fitri Kurnia Rahim*, Thunwadee Suksaroj**, Isareethika Jayasvasti**

*Institute of Health Science Kuningan (STIKes Kuningan), **ASEAN Institute for Health Development, Mahidol University, Nakhonpatthom, Thailand

\begin{abstract}
Tobacco consumption is still a burden for many countries worldwide, due to many causes attributable to smoking. Tobacco use is one of the leading global helath risks for human mortality. Further, it also responses for generating the other health risks relating with chronic diseases. The number of tobacco use has grown gradually in low-and middle-income countries. Indonesia has the highest prevalence of smoking behavior among Southeast Asian countries. This study aimed to determine predictors of smoking behavior between rural and urban areas. Data were taken from The Global Adult Tobacco Survey (GATS). This study used cross-sectional analytical study and multiple logistic regression analysis. Samples were 8,305 Indonesian adults aged $\geq 15$ years. The study showed that smokers in rural area were higher than in urban area, respectively $36.8 \%$ and $31.9 \%$. Significant predictors of smoking behavior in rural and urban areas were occupation, sex, education level, economic status as well as smoking rule inside home. In urban area, age was also significant predictor, and otherwise in rural area. The strongest predictor was smoking rule inside home and sex for smoking behavior, either in rural or in urban area.
\end{abstract}

Keywords: Adult, Indonesia, smoking, social determinant of health, tobacco

\begin{abstract}
Abstrak
Konsumsi tembakau masih menjadi beban bagi banyak negara di seluruh dunia, karena banyak penyebab disebabkan oleh rokok. Penggunaan tembakau merupakan salah satu risiko bagi kesehatan global yang dapat menyebabkan kematian manusia. Selanjutnya, hal ini juga dapat berakibat terhadap risiko kesehatan lain yang berkaitan dengan penyakit kronis. Jumlah penggunaan tembakau telah berkembang secara bertahapdi negera-negara rendah dan menengah. Indonesia memiliki prevalensi perilaku merokok tertinggi di antara negara-negara di Asia Tenggara. Penelitian ini bertujuan untuk mengetahui prediktor terhadap perilaku merokok antara wilayah pedesaan dan perkotaan. Data diambil dari Global Adult Tobacco Survey. Penelitian menggunakan studi analitik potong lintang dan analisis regresi logistik ganda. Sampel berjumlah 8.305 orang dewasa Indonesia berusia $\geq 15$ tahun. Penelitian menunjukkan bahwa perokok di wilayah pedesaan lebih tinggi dibandingkan di wilayah perkotaan, masing-masing $36,8 \%$ dan $31,9 \%$. Prediktor signifikan terhadap perilaku merokok di wilayah pedesaan dan perkotaan adalah pekerjaan, jenis kelamin, tingkat pendidikan, status ekonomi serta aturan merokok di dalam rumah. Di wilayah perkotaan, usia juga merupakan prediktor yang signifikan dan sebaliknya di wilayah pedesaan. Prediktor terkuat adalah aturan merokok di dalam rumah dan jenis kelamin untuk perilaku merokok di wilayah pedesaan atau perkotaan.
\end{abstract}

Kata kunci: Dewasa, Indonesia, merokok, determinan sosial kesehatan, tembakau

How to Cite: Rahim FK, Suksaroj T, Jayasvasti I. Social determinant of health of adult smoking behavior: differences between urban and rural area in Indonesia. Kesmas: National Public Health Journal. 2016; 11 (2): 51-55. (doi:10.21109/kesmas.v11i2.1237)

\author{
Correspondence: Fitri Kurnia Rahim, Institute of Health Science Kuningan \\ (STIKes Kuningan), Lingkar Kadugede street No. 2, Kuningan, West Java, \\ Indonesia, Phone: +62232-875867,e-mail: fikura.zone@gmail.com \\ Received: November $10^{\text {th }} 2016$ \\ Revised: November $30^{\text {th }} 2016$ \\ Accepted: November $30^{\text {th }} 2016$
}




\section{Introduction}

Since tobacco use remains a health problem in many countries, World Health Organization (WHO) forecasts that tobacco use would kill almost eight million people annually by $2030.1,2$ The increasing of death caused by tobacco use occurs in developing countries. Moreover, many diseases are attributable to tobacco use. Smoking cigarette is one of common products consumed by people worldwide. ${ }^{3}$

Among Southeast Asian countries, Indonesia has the highest adult smoking prevalence. ${ }^{4}$ Indonesia's smoking prevalence is still high on adult population. ${ }^{5}$ During the age, adults are normally at productive time. Sometimes, tobacco use might decrease productivity of people. Also, it has become the major contributor for country's morbidity and mortality. ${ }^{5}$ However, government's willingness for regulation implementation of tobacco control program is low. Framework convention on tobacco control has not been ratified by Indonesian government; otherwise, other Southeast Asian countries did it already.6,7 That is why the high prevalence of smoking occurs in Indonesia. As Indonesia has many islands, it may arise gap between rural and urban areas. Nevertheless, in term of smoking behavior, residence place gap of smoking behavior may be different between rural and urban areas. Prior study found that predictors for smoking behavior between rural and urban areas were different. Rural area had higher smoking prevalence than urban. This study examined predictors of smoking by different residence place.

\section{Method}

This study used The Global Adult Tobacco Survey (GATS) in 2011. The GATS concerned on a nationally representative household survey among adult aged $\geq 15$ years old, with an overall response rate of $94.3 \% .^{8}$ The data collection procedure was face-to-face personal interview. Handheld devices were used for electronic data collection. Cross-sectional analytical study estimated for the country as a whole, as well as by urban city, either rural or urban residence had been shown in this study. The survey used sampling frame from Census Blocks which is obtained from the population census of Indonesia Central Statistics Agency (Badan Pusat Statistik) in May 2010. Stratified four cluster sampling was applied in this study. As many as 8,305 samples were involved. ${ }^{8}$

The standardized questionnaires of global tobacco by using optional question were applied for measurement. ${ }^{8}$ From this measurement, smoking behavior was assigned as dependent variable which divided two categories of smokers. Daily and non-daily smokers of any cigarette product was coded as 0 , while non-smokers both former and never be smoker was coded as 1 . Independent variables were sociodemographic and smoking rule inside home. The variables related to social demographic used in this analysis were sex (male/female), age, occupation, residence place (ur- ban/rural), education, economic status (poor/middle/rich), and number of person living in one household.

In this study, occupation consisted of four categories that were civil servant/non-government employee was coded as 0 ; self-employed/subsistence farming/home maker was coded as 1; student was coded as 2 ; and unemployed (able/unable to work/retired) was coded as 3 . For education level, it had three categories that were college/university completed - postgraduate degree completed was coded as 0 ; secondary school completed high school completed was coded as 1; less than primary school completed - primary school completed was coded as 2. Moreover, for smoking rule inside home, this study categorized the tolerance of smoking rule use into three categories that were yes tolerance if the answer was allowed and no rule which was coded as 0 ; partial tolerance if the answer was not allowed but exceptions which was coded as 1; and no tolerance if the answer was never allowed which was coded as 2 .

All adult data were used for this analysis. Residence place of respondents was being considered for each test analysis. The estimates for prevalence were reported as by percentage or composition with $95 \%$ confidence intervals (CI). Chi square test was used to examine relations between smoking behavior and sociodemographic as well as smoking rule inside home variables. A p value $<0.05$ was considered statistically significant. Multivariate logistic regression was applied to determine predictor of smoking behavior. All statistical analysis was using SPSS 18.0 software.

\section{Results \\ Smoking Behavior}

Table 1 showed residence place differences in sociodemographic and smoking behavior prevalence. According to characteristic of composition, as compared to urban area, rural area showed a slightly higher proportion of smoker. Totally, the proportion of smokers in rural was about 1.2 times higher than urban area, 0.368 and 0.319 respectively. In comparison with urban composition, rural was higher proportion in age $\geq 45$ years, selfemployee/subsistence farming/home maker of occupation group, female, less than primary school completed, middle economic status, four and less than number of person living, and tolerance tobacco use inside home in term of smoking rule. The proportion of smoker in $25-44$ years of age category was higher in urban than rural. In term of occupation, urban had higher smoker proportion, except among those working as self-employee/subsistence farming/home maker. On sex characteristic, smoker in rural was much higher than urban. For other variables, among those who had high school completed and lower, rich economic status, no and partial tolerance of tobacco use insider had higher proportion in urban than rural areas. 
Table 1. Description and Pattern of Current Smoking among Adults in Indonesia by Residence Places

\begin{tabular}{|c|c|c|c|c|c|c|c|}
\hline \multirow{2}{*}{ Variable } & \multirow{2}{*}{ Category } & \multicolumn{3}{|c|}{ Composition (\%) } & \multicolumn{3}{|c|}{ Current Smoking (\%) } \\
\hline & & Rural & Urban & Difference & Rural & Urban & Difference \\
\hline \multirow[t]{2}{*}{ Smoking behavior } & Non-smoker & 0.632 & 0.681 & -0.049 & - & - & - \\
\hline & Smoker & 0.368 & 0.319 & 0.049 & - & - & - \\
\hline \multirow[t]{4}{*}{ Age } & & & & & $<0.001$ & $<0.001$ & \\
\hline & $15-24$ years & 0.142 & 0.179 & 0.040 & 0.040 & 0.040 & 0 \\
\hline & $25-44$ years & 0.421 & 0.501 & 0.166 & 0.166 & 0.171 & -0.005 \\
\hline & $\geq 45$ years & 0.401 & 0.320 & 0.162 & 0.162 & 0.108 & 0.054 \\
\hline \multirow[t]{5}{*}{ Occupation/work status } & & & & & $<0.001$ & $<0.001$ & \\
\hline & Civil servant/non-government employee & 0.218 & 0.347 & 0.107 & 0.107 & 0.154 & -0.047 \\
\hline & $\begin{array}{l}\text { Self - employee/subsistence } \\
\text { farming/home maker }\end{array}$ & 0.669 & 0.501 & 0.236 & 0.236 & 0.125 & 0.111 \\
\hline & Student & 0.042 & 0.073 & 0.007 & 0.007 & 0.010 & -0.003 \\
\hline & Unemployed/retired & 0.070 & 0.078 & 0.019 & 0.019 & 0.028 & -0.009 \\
\hline \multirow[t]{3}{*}{ Sex } & & & & & $<0.001$ & $<0.001$ & \\
\hline & Female & 0.530 & 0.519 & 0.020 & 0.020 & 0.012 & 0.008 \\
\hline & Male & 0.470 & 0.481 & 0.368 & 0.386 & 0.306 & 0.062 \\
\hline \multirow[t]{4}{*}{ Education level } & & & & & $<0.003$ & 0.018 & \\
\hline & $\begin{array}{l}\text { College/university - postgraduate } \\
\text { degree completed }\end{array}$ & 0.033 & 0.106 & 0.256 & 0.008 & 0.028 & -0.02 \\
\hline & Secondary - high school completed & 0.292 & 0.507 & 0.104 & 0.104 & 0.160 & -0.056 \\
\hline & $\begin{array}{l}\text { Less than primary school } \\
\text { completed - primary school completed }\end{array}$ & 0.675 & 0.386 & 0.008 & 0.256 & 0.131 & 0.125 \\
\hline \multirow[t]{4}{*}{ Economic status } & & & & 0.024 & 0.003 & & \\
\hline & Rich & 0.120 & 0.196 & 0.043 & 0.043 & 0.053 & -0.01 \\
\hline & Middle & 0.488 & 0.521 & 0.190 & 0.190 & 0.175 & 0.015 \\
\hline & Poor & 0.392 & 0.283 & 0.135 & 0.135 & 0.091 & 0.044 \\
\hline \multirow[t]{3}{*}{ Person living member } & & & & & 0.937 & 0.782 & \\
\hline & $\leq 4$ & 0.741 & 0.703 & 0.273 & 0.273 & 0.225 & 0.048 \\
\hline & $>4$ & 0.259 & 0.297 & 0.095 & 0.095 & 0.094 & 0.001 \\
\hline \multirow[t]{4}{*}{ Smoking rule } & & & & & $<0.001$ & $<0.001$ & \\
\hline & No tolerance & 0.025 & 0.153 & 0.004 & 0.004 & 0.025 & -0.021 \\
\hline & Partial tolerance & 0.121 & 0.196 & 0.030 & 0.030 & 0.053 & -0.023 \\
\hline & Tolerance & 0.849 & 0.638 & 0.369 & 0.369 & 0.241 & 0.128 \\
\hline
\end{tabular}

\section{Predictors of Smoking Behavior}

Table 2 showed the adjusted odds ratio (AOR) of smoking in rural and urban areas regarding to multivariate logistic regressions analysis. In rural, aging did not significantly related with smoking. Student (AOR: 0.632; 95\% CI: 0.238-0.550) and unemployed (able or unable) and retired (AOR: 0.163; 95\% CI: 0.093-0.285) of occupation groups were a significant predictor of smoking. Those groups were less likely to smoke than those working as civil servants and non-government employees. Sex was also a significant predictor of smoking. Males were more likely to smoke than females (AOR: 97.003; 95\% CI: 74.689-125.984). Hence, secondary-high school completed groups (AOR: 2.303; 95\% CI: 1.355-3.912) and primary school completed and lower (AOR: 3.336; 95\% CI: 1.983-5.610) were positively a predictor of smoking. Those groups were more likely to smoke than the high level of education. In addition, poor economic also significantly related to smoking (AOR: 1.573 ; 95\% CI: 1.112-2.123), but negatively on middle economic status. Poor condition among rural population was more likely to smoke. In term of smoking rule, full tolerance of tobacco use inside home was significant predictor (AOR:
4.364; 95\% CI: 2.212-8.608), but negatively for partial tolerance. Adult who had full tolerance of tobacco use inside home was more likely to smoke.

Unlike urban, aging did not significantly related in the old age period $\geq 45$ years old, but negatively in the middle age group of $25-44$ years. Specially, compared to age groups of $15-24$ years old, those age groups of $25-44$ years were 1.4 times more likely to smoke (AOR: 1.432; 95\% CI: 1.035-1.982). Hence, the same pattern with rural area, secondary-high school completed groups (AOR: 0.228; 95\% CI: 0.144-0.361) and primary school completed and lower (AOR: 0.656; 95\% CI: 0.460-0.935) was positively a predictor of smoking behavior. Those levels of education groups were more likely to smoke than the high level of education. Similar with rural, males were likelihood to smoke compared to female (AOR: 109.924; 95\% CI: 79.499-151.994). In addition, poor economic significantly related to smoking (AOR: 1.513; 95\% CI: 1.113-2.056), but negatively on middle economic status. Poor condition among urban population was more likely to smoke. Unlike in rural, fully (AOR: 3.692; 95\% CI: 2.774 - 4.913) and partial tolerance (AOR: 1.903; 95\% CI: 1.374-2.636) of tobacco use in- 
Table 2. Predictors of Current Smoking among Adults in Indonesia by Residence Place

\begin{tabular}{|c|c|c|c|c|c|c|c|}
\hline \multirow{2}{*}{ Variable } & \multirow{2}{*}{ Category } & \multicolumn{3}{|c|}{ Rural (n=4203) } & \multicolumn{3}{|c|}{ Urban $(n=4102)$} \\
\hline & & AOR & $95 \%$ CI & p value & AOR & $95 \% \mathbf{C I}$ & p value \\
\hline \multirow[t]{3}{*}{ Age } & $15-24$ years & 1 & & & 1 & & \\
\hline & $25-44$ years & 1.170 & $0.829-1.654$ & 0.372 & 1.432 & $1.035-1.982$ & 0.030 \\
\hline & $\geq 45$ years & 1.412 & $0.987-2.020$ & 0.059 & 1.211 & $0.858-1.709$ & 0.276 \\
\hline \multirow[t]{4}{*}{ Occupation/work status } & Civil servant/non-government employee & 1 & & & 1 & & \\
\hline & $\begin{array}{l}\text { Self - employee/subsistence } \\
\text { farming/home maker }\end{array}$ & 0.871 & $0.685-1.106$ & 0.871 & 1.002 & $0.800-1.255$ & 0.986 \\
\hline & Student & 0.163 & $0.093-0.285$ & $<0.001$ & 0.228 & $0.144-0.361$ & $<0.001$ \\
\hline & Unemployed/retired & 0.362 & $0.238-0.550$ & $<0.001$ & 0.656 & $0.460-0.935$ & 0.020 \\
\hline \multirow[t]{2}{*}{ Sex } & Female & 1 & & & 1 & & \\
\hline & Male & 97.003 & $74.689-125.984$ & $<0.001$ & 109.924 & $79.499-151.994$ & $<0.001$ \\
\hline \multirow[t]{3}{*}{ Education level } & $\begin{array}{l}\text { College/university - postgraduate } \\
\text { degree completed }\end{array}$ & 1 & & & 1 & & \\
\hline & Secondary - high school completed & 2.303 & $1.355-3.912$ & 0.002 & 1.533 & $1.125-2.089$ & 0.007 \\
\hline & $\begin{array}{l}\text { Less than primary school } \\
\text { completed - primary school completed }\end{array}$ & 3.336 & $1.983-5.610$ & $<0.001$ & 2.441 & $1.715-3.473$ & $<0.001$ \\
\hline \multirow[t]{3}{*}{ Economic status } & Rich & 1 & & & 1 & & \\
\hline & Middle & 1.291 & $0.955-1.746$ & 0.097 & 1.103 & $0.858-1.417$ & 0.446 \\
\hline & Poor & 1.573 & $1.112-2.123$ & 0.009 & 1.513 & $1.113-2.056$ & 0.008 \\
\hline \multirow[t]{3}{*}{ Smoking rule } & No tolerance & 1 & & & 1 & & \\
\hline & Partial tolerance & 1.463 & $0.709-3.016$ & 0.303 & 1.903 & $1.374-2.636$ & $<0.001$ \\
\hline & Tolerance & 4.364 & $2.212-8.608$ & $<0.001$ & 3.692 & $2.774-4.913$ & $<0.001$ \\
\hline
\end{tabular}

side home were significant predictors of smoking behavior. Both those whod had full and partial tolerance of tobacco use were more likely to smoke than those who had no tolerance of tobacco use inside home.

\section{Discussion}

Study findings indicated that current smoking prevalence was slightly the same between rural and urban areas, $36.8 \%$ and $31.9 \%$ respectively. Small number was found for the prevalence of differences of smoking in accordance with residence place. However, rural area had higher proportion of smoking than urban areas. This trend had the same pattern with prior national study. ${ }^{9-11}$ Studies in Bangladesh and China found the same as current finding that rural had higher tobacco smoking than urban. ${ }^{12,13}$ Basic Health Research (Riset Kesehatan Dasar) from 2007-2010 depicted that rural had higher smoker than urban area.9-11 As well as the increasing number of smoking prevalence occurred during that year both in rural and urban areas. This study presented that smoking among rural area, however, was approximately 1.01 fold lower than the national survey rate in 2010 . As well as the difference of smoker in both areas was $5 \%$ as reported by Basic Health Research in 2010. ${ }^{10}$ Recently, Indonesia faces smoking problem, which was the same problem in both rural and urban areas in Indonesia. Attention should be given to develop an intervention program in both areas. Framework Convention on Tobacco Control (FCTC) is an agreement that has already been effective in tobacco control program among international community, however, Indonesia has not yet ratified. ${ }^{14}$

The aim of current study was to provide the predic- tors of adult smoking behavior by residence place differences both in rural and urban areas. According to the results obtained here, the predictors between rural and urban were different. For rural area, occupation, sex, education level, economic status, and tolerance of tobacco use inside home were significant predictors.

Similarly, the significant predictors of smoking behavior were the same as in rural predictors, however, adding more one significant predictor that was age variable. Among urban area, people at the age group of $25-$ 44 years were more likely to smoke. In addition, the high prevalence of urban smoker was the highest in that period of age group $(50.1 \%)$. It was shown also in Bangladesh finding that the increasing proportion of smoker was from the age of 25-54 years. ${ }^{1}$ Similar to another finding, among adult men in Pakistan, age was significant predictor for current cigarette smoking. It showed that the older people the more likely to smoke. ${ }^{15}$ The decreasing of smoker in the older age might be due to several reasons, one of which was the occurrence of severe diseases faced by that group, which means that they needed to quit smoking or they were died already. The early age group of adult should be concerned in order to be target population of tobacco control program. This might boost the productivity of adult population in their working activities. Moreover, adult population might be imitated by the young generation, which means that while they were being parents, their children might follow their behaviors. One finding explained that parental smoking related to a higher risk of lifetime experimental smoking among urban men. ${ }^{13}$

In addition, sex factor has been found as significant 
predictors to smoking behavior either rural or urban areas. As males are more likely to smoke than females, it will be implications to economic stability of every household. It is because tobacco consumption exhibits a myopic addiction, meaning that the smoker is irrational behavior. ${ }^{16}$ Then the demand of cigarette for smoker would be increased in the future.

In term of smoking rule inside home, the current study showed that in rural, those who had full tolerance of smoking inside home were significantly a predictor of smoking behavior, while in urban, the significant predictors were partial and full tolerance of smoking inside home. In other words, the more population did not have the smoking rule inside home (allow smoking inside home), it might raise the chance for people to smoke. Developing smoke-free homes for both areas of residence was very important. By building smoke-free home regulation, it is not only trying in reduction of smoking, but also will protect the whole household members from second hand smoke exposure. ${ }^{17}$

\section{Conclusion}

This study provides important information in identifying the differences pattern between rural and urban areas, in explaining about the most influential factors of smoking behavior among adults. Smoker in rural area were higher than in urban area, $36.8 \%$ and 31.9 respectively. Occupation, sex, educational level, economic status as well as smoking rule inside home factors were found to be significantly associated with cigarette smoking behavior. The finding showed that age factor and smoking behavior in rural area appears to be significantly associated, particularly among age $\geq 45$ years old, otherwise, in urban area is among age 25-44 years old. Moreover, those particular ages require a comprehensive prevention program. In addition, sex and tolerance of tobacco use inside home have been found as the strongest predictors of smoking behavior among Indonesian adults either in rural or urban areas.

\section{Recommendation}

This study recommends developing smoke-free home regulation and increasing the tobacco control program according to target population approaches. Due to a little different pattern of smoking rule predictors between rural and urban areas, urban area has to show more effort for implementing the complete smoking regulation in term of smoking bans inside home. In addition, tobacco control program should be relatively increased by considering the appropriate target population both in rural and urban areas. Particuraly, the middle age of adult population should be given attention for tobacco control program. Moreover, sex perspective also should be involved in tobacco control program. As males are more likely to smoke than females.

\section{References}

1. World Health Organization. WHO report on the global tobacco epidemic. Raising taxes on tobacco. Geneva, Switzerland: World Health Organization; 2015 [cited Aug 15 2016]. Available from: www.who.int.

2. World Health Organization. WHO report on the global tobacco epidemic. The MPOWER package. Geneva: Switzerland; 2008 [cited January 4 2016]. Available from: http://apps.who.int/iris/bitstream/10665/43818/1/9789241596282_eng.pdf.

3. Eriksen M, Mackay J, Schluger N, Gomeshtapeh FI, Drope J. The tobacco atlas. 5th edition. Brighton: The American Cancer Society; 2015.

4. Lian TY, Dorotheo U. The ASEAN tobacco control atlas. 2nd edition. Bangkok, Thailand: South East Asia Tobacco Control Alliance; 2014.

5. Eriksen M, Mackay J, Schluger N, Gomeshtapeh FI, Drope J. The tobacco atlas Indonesia. Factsheet, 2015 [cited January 2016]. Available from: http://www.tobaccoatlas.org/country-data/indonesia/.

6. McDonald P, Utomo ID, Utomo A, Reimondos A, Hull T. The 2010 greater Jakarta transition to adulthood survey policy brief No. 3 early childhood education and care for disadvantaged families. Canberra: Australian National University; 2011.

7. World Health Organization. WHO Report on the global tobacco epidemic [Facsheet]. 2015[cited October 20, 2015]. Available from: http://www.who.int/tobacco/surveillance/policy/country_profile/idn.pd f?ua $=1$.

8. World Health Organization. Global adult tobacco survey: indonesia report 2011. Jakarta: National Institute of Health Research and Development Ministry of Health; 2011.

9. Kementerian Kesehatan Republik Indonesia. Laporan Riset Kesehatan Dasar 2007. Jakarta: Pusat Penelitan dan Pengembangan Kesehatan Kementerian Kesehatan Republik Indonesia; 2007.

10. Kementerian Kesehatan Republik Indonesia. Laporan Riset Kesehatan Dasar 2010. Jakarta: Pusat Penelitan dan Pengembangan Kesehatan Kementerian Kesehatan Republik Indonesia; 2010.

11. Kementerian Kesehatan Republik Indonesia. Laporan Riset Kesehatan Dasar 2013. Jakarta: Pusat Penelitan dan Pengembangan Kesehatan Kementerian Kesehatan Republik Indonesia; 2013.

12. Palipudi KM, Sinha DN, Choudhury S, Zaman MM, Asma S, Andes L, et al. Predictors of tobacco smoking and smokeless tobacco use among adults in Bangladesh. Indian Journal of Cancer. 2012;49 (4): 387-92.

13. Ma H, Unger JB, Chou C-P, Sun P, Palmer PH, Zhou Y, et al. Risk factors for adolescent smoking in urban and rural China: findings from the China seven cities study. Addictive Behaviors. 2008; 33(8): 1081-5.

14. Achadi A. Regulasi pengendalian masalah rokok di Indonesia. Kesmas: Jurnal Kesehatan Masyarakat Nasional. 2008; 2(4): 161-5.

15. Gilani SI, Leon DA. Prevalence and sociodemographic determinants of tobacco use among adults in Pakistan: findings of a nationwide survey conducted in 2012. Population Health Metrics. 2013; 11 (1): 16.

16. Hidayat B, Thabrany H. Model spesifikasi dinamis permintaan rokok: rasionalkah perokok Indonesia?. Kesmas: Jurnal Kesehatan Masyarakat Nasional. 2008; 3 (3): 99-108.

17. Nichter M, Padmajam S, Nichter M, Sairu P, Aswathy S, Mini GK, et al. Developing a smoke free homes initiative in Kerala, India. BMC Public Health. 2015;15 (1): 480. 